\title{
Politics of John Donne's Devotions Upon Emergent Occasions: or, New Questions on the New Historicism
}

\author{
MARY ARSHAGOUNI
}

\section{E} ntered in the Stationers' Register on January 9, 1624, ${ }^{1}$ and dedicated to Prince Charles, John Donne's Devotions upon Emergent Occasions traditionally has been read as a meditative exercise that moves from a mood of anxiety to peace and reconciliation with God. ${ }^{2}$ It has also been interpreted as a work that offers pointed political advice to King James, an approach that has attracted those whose interests lie in examining the political and historical contexts of works. Robert Cooper's 1977 essay, "The Political Implications of Donne's Devotions," for example, interprets the Devotions as a warning to the King against falling under the influence of Rome. ${ }^{3}$ But in my view, this new historicist perspective ultimately fails to solve critical problems in the work. Much of the difficulty in reading the Devotions along these lines arises from faulty assumptions regarding Donne's political orientation at the time he composed the Devotions, a view that highlights the striking politicization of Donne's life and works from as early as 1640. In this article, therefore, I would like to re-examine the historical and political context of the Devotions, re-consider the way in which Donne's life and writings have been politicized, and question the appropriateness of applying a new historicist methodology for interpreting a work like the Devotions.

Let us begin with an examination of the political/historical context that Cooper presents and consider whether such a reading is in fact tenable. This re-examination is particularly important, for Cooper's interpretation of the political role that Donne intended his Devotions to play seems to have become the accepted view of Donne's political concerns in early 1624, as Arthur Marotti's recent affirmation of Cooper's assertions suggests. In his analysis, Cooper finds the traditional meditative view of the Devotions as an account of Donne's recovery from sickness and ultimate reconciliation with God "insufficient." In Cooper's words, the traditional meditative view of the 
Devotions "does not explain why Donne chooses to fill the work with an almost endless webbing of political imagery." In addition to any spiritual movement, he explains, Donne also issues a political warning to King James, urging him to be on guard against the Roman Church and the dangers of "relapsing" into Catholic idolatry. He develops this argument by describing the politically sensitive situation in England in 1623-24 and by noting Donne's own personal reasons for taking a subtle approach in warning James, not a direct one. As he stresses the unrest that he thinks English protestants would have felt in 1623-24 as they anticipated the Spanish match, Cooper goes on to suggest that because Donne had "fallen at least once into the king's disfavor, [he] was likely to be extremely cautious about any comment he might wish to make concerning royal 'inclining to Popery'." Ultimately the argument rests on the notion that "Donne could hardly have been unaware of these possibilities when he readied the Devotions for the press and prepared to dedicate them to Charles Stuart."4

All of this may sound appealing at first glance. But Cooper's political analysis suffers from an inaccurate description of the historical context of the work. First, it accepts Walton's account of the King's displeasure with Donne at face value and thus concludes that Donne had in fact fallen into disfavor as a result of his pulpit arguments against the Roman Church. Convincing as this may sound, the facts do not bear out such a conclusion. As David Novarr and Judith Anderson have clearly demonstrated, care must be used in reading Walton. ${ }^{5}$ According to the story in the Life of Donne, Donne "was once, and but once, clouded with the King's displeasure ... which was occasioned by some malicious whisperers, who had told his majesty that Dr. Donne had put on the general humor of the Pulpits, and was become busie in insinuating a fear of the Kings inclining to Popery, and a dislike of his government." Other interpretations of these facts are beginning to come forward. According to Donne's modern biographer, R.C. Bald, for example, "the incident makes a pleasant story and is told very circumstantially, but it is suspect none the less." He suggests that Walton has perhaps confused this with "a well-authenticated incident which occurred in the next reign when Donne was suspect for a brief period and successfully cleared himself after an interview with Charles I."6 Paul R. Sellin agrees with Walton, that this incident occurred during James' reign, but he reads it in an entirely different context. In his view, the king's displeasure may have resulted from attempts to discredit Donne, not for speaking out against Papism, but rather for speaking out in support of Bohemia, following his return to England from the Palatinate and the Netherlands in 1620 , a point to which we will return shortly. ${ }^{7}$ In brief, Walton's 
suggestion that Donne had been chastized for speaking out against Romanism is suspect, and one certainly should be circumspect about basing conclusions on it.

Second, the account of the Directions to Preachers is also subject to correction. While Cooper, seconded by Marotti, states that James issued the Directions in hopes of quieting the discontent that had arisen as a result of the secret trip to Spain that Prince Charles and Buckingham had undertaken, this cannot be correct. The Directions were issued on August 4, 1622, whereas Charles and Buckingham did not set off on their voyage until February 28 . 1623. Cooper's inversion of these two events may well result from confusion between old and new style dating. The Directions arose, rather, from discontent over James's failure to respond to the struggle in Europe where danger to the Palatinate was growing. ${ }^{8}$ Though greatly distressed by the threat to protestantism in Europe and the failure of his sovereign to respond to the crisis, Donne does not permit himself at this time generally to indulge in any overt expression of doubt about the King's "constancie in the true reformed religion." Although his whole heart may not have been in his "Sermon upon the XX. verse of the V. Chapter of the Booke of Judges. Wherein occasion was justly taken for the Publication of some Reasons, which his Sacred Majestie had been pleased to give, of those Directions for Preachers, which hee had formerly sent foorth," preached at Paul's Cross on September 15, 1622, Donne nevertheless speaks in favor of the King's order, rather than as the King's critic. ${ }^{9}$ In a letter to Sir Henry Goodere written but a week later, Donne explains that because many were distressed by the King's orders, he

had commandment to publish them in a Sermon at the Crosse, to as greal a Congregation as ever [he] saw together, where they received comfortable assurance of his Ma[jes]ties constancy in Religion, and of his desire that all men should be bred in knowledge of such things, as might preserve them from the superstilion of 'Rome'. ${ }^{10}$

Professing himself pleased with the sermon, the King ordered it printed, and called it, according to Doncaster, "a piece of such perfection as could admit neither addition nor diminution." "l However he may have felt personally, Donne never goes so far as to criticize James in this sermon. Quite the contrary, he urges patience. In fact, he even complains to Sir Thomas Roe that "to conclude the worst upon the first degree of ill is a distilling with too hot a fire." He tells Roe as well that "Some weeks after that I preached another at the same place, upon the Gunpowder Day; therein I was left more to mine own liberty." 12 His expression hardly implies that he ran the risk of royal 


\title{
236 / Renaissance and Reformation
}

displeasure. In case any doubt remains, Donne's Gunpowder Day sermon preached "upon the fift of November 1622" best illustrates the contrary. Here Donne clearly plays the role of royal apologist. He demonstrates publicly his commitment to King James, praising him as the symbol of peace, and the heart and breath of the nation. "In the presence of the Head of the whole Church, who is All in all," he declares,

\begin{abstract}
I ... doe deliver that, which upon the truth of a Morall man, and a Christian man, and a Church man, beleeve to be true, That hee, who is 'the Breath of our nostrils,' is in his heart, as farre from submitting us to that Idolatry, and superstition, which did heretofore oppresse us, as his immediate Predecessor, whose memory is justly precious to you, was: Their wayes may be divers, and yet their end the same, that is, The glory of God; And to a higher Comparison, to her, I know not how to carry it. ${ }^{13}$
\end{abstract}

In light of Donne's own public statements in support of James, it secms hard to argue that Donne entertained real fear of James's return to 'popery.' Far from criticizing the King, Donne's response to the Directions to Preachers expresses explicit faith in James's 'constancie in religion', however much he may have been troubled by the events in Bohemia and the fall of Heidelberg in September 1622. If anything, the issues and "politics" behind the Devotions may be more closely connected with the events in Bohemia than with any real fear that James would convert to Catholicism.

Third, in describing the political climate which existed when Donne wrote the Devotions, the analysis put forth by Cooper and Marotti (who describes Donne as a "sanctioned religiopolitical spokesman"), ${ }^{14}$ focuses exclusively on the possibility of a marriage between Charles and the Spanish Infanta and completely ignores the dangers facing protestantism in Europe. Any review of contemporary documents and correspondence, whether public or private, however, reveals that from 1619 onward the plight of James's daughter and son-in-law, the Queen and King of Bohemia, consumed the mind and heart of England, including Donne's. ${ }^{15}$ After the fall of Heidelberg in September 1622, an event which Donne chronicled in his letters to Goodere, attitudes towards the Spanish match changed. Whereas before 1623 it had been viewed with dread, after the fall of Heidelberg it slowly became intertwined with the restoration of the Palatinate in the minds of the English people, their King, and their Prince. Indeed, by late 1623 fear of the Spanish match had waned, and upon the return of Charles and Buckingham from Spain in October 1623, when it was clear that the match was unlikely to proceed, the whole country breathed a collective sigh of relief. ${ }^{16}$ Rather than encouraging the Papists in 
England, Charles's return seems to have hurt their position. As early as June 16, 1623, the Venetian' Ambassador in London writes that "the Protestants here, laying aside their great repugnance of old, seem better disposed to this marriage. This increases the suspicion of the Spaniards that they have been assured it will not cause them any prejudice." And on January 3, 1624, John Chamberlain writes to Dudley Carleton, "We talke of a proclamation likewise shortly to come foorth against priests and Jesuites ... which makes the papists hang downe their heades, and looke for no goode for their turne by this parlement."17 After nearly a decade of real crisis because of the Spanish match, why would Donne, in early 1624, in a work dedicated to Charles, reverse his position and suddenly attempt to warn James of the dangers of a Spanish match that was unlikely to take place anyhow? Even though in January 1624 the match had not definitely been called off, it was clear that no such marriage would take place before the restoration of the Palatinate, and in any event, even the conclusion of such a match in 1624 was not necessarily good news for papists. In short, there is no evidence that in early 1624, precisely at the time Donne readied his Devotions for press, either James or Charles would be likely even to go through with a Spanish match, much less return the country to the influence of Rome.

The argument that James would return the country to the influence of Rome is faulty in other respects too, for it makes no mention of the troubles afflicting James' daughter and son-in-law in Bohemia. This glaring omission underscores two important problems: 1) faulty assumptions regarding Donne's political orientation and concerns in early 1624, and 2) the tendency of most Renaissance historicists to focus almost exclusively on issues of domestic policy at the expense (and at times to the exclusion) of those of foreign policy. Let us examine the initial problem first. Many scholars today consider Donne a via media Anglican with Catholic leanings arising from his Papist upbringing - an assumption that is clear in their tendency to view Loyola's Spiritual Exercises as Donne's primary model for the Devotions. ${ }^{18}$ But when one re-examines the earliest biographies of Donne, particularly Walton's 1640 Life of Donne, it becomes clear that Donne's life and writings have been politicized from the time of his death and that, consciously or unconsciously, modern assumptions generally have followed along these lines. In a recent study on Walton's biography of the late churchman, Judith Anderson asserts that Walton's "Life of the holy Dr. Donne [first published in 1640 and revised continually until 1675] is an artificial saint's Life - not an untruth certainly, but a fiction." Indeed, she goes on to explain, "Walton's role in The Life is interpretative, and it is also openly inventive. ... Walton may blend his facts 
with his point of view but the resulting image is one we should recognize as artificial, contrived, or even fictional." 19 What is most striking about the portrait of Donne presented in the Life is Walton's interest in presenting a holy man with strong ties to the Anglican church. Fittingly, the climax in this "story" occurs at the moment of Donne's calling. While the biographical methods employed by Walton "leave us with Walton's picture of Donne, a real seventeenth-century view of a real life lived in historical time," 20 it is important to recognize the political biases that would have led Walton in early 1640 to place Donne strongly in the "Anglican" camp, a perspective that assumes that Donne would have focused his attentions on Anglo/Catholic issues such as the Spanish match, and not on the profound dangers threatening sister Protestant churches in Europe. Despite statements by Donne's son in 1640 and by more recent scholars that recognize that the political climate had changed drastically between 1624 and 1640, modern scholars like Cooper and Marotti persist in rehearsing assumptions underlying Walton's Life of Donne that read Donne as a post-Laudian "Anglican" with strong antipathies to radical puritanism in Europe and at home rather than as a pre-Laudian clergyman with deep feelings of kinship with suffering protestant churches in Europe. In 1624, one could certainly be a Calvinist within the established church - indeed, as some argue, the established church was Calvinist. ${ }^{21}$ But by 1640 , on the verge of civil war, the country divided along lines that simply did not exist in pre-Laudian times. ${ }^{22}$ Consequently, a post- 1640 perspective often fails to recognize the close affinities that had existed between those who served in the Church of England such as Donne and the Calvinist churches in Germany and the Low Countries. Unfortunately, this later perspective remains the bias of many literary scholars concerned with Renaissance and Reformation issues today.

Let us now turn to the second issue, that of the tendency of Renaissance historicists to focus almost exclusively on domestic policy to the near exclusion of foreign policy concerns. As Professor Sellin has recently recognized,

a serious flaw in much current historicism, whether "new" or antiquated, is its seeming reluctance to connect English literature of the Renaissance and early seventeenth century with anything other than domestic politics and patronage, almost to the point of effectively excluding from consideration even large matters involving foreign policy or relations with the Continent and the world abroad. ${ }^{23}$

While Cooper's attempt to link Donne's politics with concerns of foreign policy - the concerns in England with the events occuring in Spain - is a 
welcome change from the traditional approach, Sellin suggests a very different political context and description of Donne's political preoccupations and disappointments in the early 1620's on the eve of his composition of the Devotions. After describing Donne's experiences with the mission to the Continent in 1619-1620 led by the King's favorite James Hay, Viscount Doncaster, Sellin outlines the extreme disappointment that Donne probably experienced after Doncaster's failure to move James to become actively engaged in support of the Palatinate. ${ }^{24}$ Rather than manifesting concern for the possibility that James might return the country to the influence of Papism as Cooper and Marotti had suggested, Donne rather showed concern for James' failure to act on behalf of the Palatinate. The distinction is more than merely a question of emphasis. In this context, the conclusion that "politically Donne shared the enthusiasm that Doncaster and Nethersole felt for the Bohemian cause, for Frederick's accepting the crown at Prague, and for militant support of the Calvinist Dutch against the house of Spain and Austria" demonstrates the passion with which Donne held the plight of the Queen of Hearts in 1622, a fervor that deteriorated into extreme disappointment when James failed to heed the advice of Doncaster and Donne. Although following the mission to the Continent with Doncaster, "Donne was to live another decade," he "never went abroad again." More importantly, "in the many crises that English foreign policy was soon to undergo, his talents and experience were never again put to use in this way." 25 Indeed, rather then showing concern for the possibility that James might return the country to Papism, the politics behind the Devotions might reflect Donne's extreme disappointment at the failure of his mission with Doncaster to the Continent and the failure of James to act decisively on behalf of the Palatinate. In this context, as we shall see, the Devotions becomes anything but a work offering the kind of political advice that Cooper describes.

If, as I think, Donne's political and religious orientation in 1623-24 differed from what most scholars generally have assumed, then the position that Donne feared James would return the country to Papism is untenable. However, simply correcting historical facts does not address the underlying methodology. Should a work like the Devotions really be subjected to a political/new historicist reading? Cooper and Marotti thought the critical solution to problems in the text lay in politics, but politics as inferred from imagery considered to be political. ${ }^{26}$ The first question that arises from this method concerns the "endless webbing of political imagery" traced throughout the Devotions. Does the mere presence of allusions to kingship and society allow readers to interpret the Devotions as a work which has a specific and 
definable political intent, as a new historicist reading does? A glance through the "political" imagery that Donne's speaker employs in the Devotions imagery that lies side-by-side his numerous scientific and natural allusions reveals Donne's dexterity in manipulating the familiar microcosm $/ \mathrm{macro-}$ cosm correspondences, as he has his speaker constantly draw comparisons between his person, the natural world, and society at large. Do these "political" images really differ from the other sorts present? Rather than attempting to offer political advice, all of them, including the "political," stress the fragility of mankind in comparison to the greatness and majesty of God - an important element in humility and pietism. But is this not more a question of private ethics than public political policy? In Expostulation II, for example, Donne's speaker makes reference to the biblical King David in order to remind us that "No man is so little, in respect of the greatest man, as the greatest in respect of God." Similarly, he says in Meditation III, "a fever can bring that head, which yesterday carried a crown of gold five feet towards a crown of glory, as low as his own foot to-day." And again, "A glass is not the less brittle, because a king's face is represented in it; nor a king the less brittle, because God is represented in him. ... They are gods, but sick gods" (Med.VIII). ${ }^{27}$ It is hard to see how such instances as these constitute clear advice on public policy.

In a similar vein, Donne's speaker praises King James in Expostulation VIII, not simply for encouraging Donne to take Orders, but more importantly as an agent through whom God works His will. "But this his assisting to my bodily health, thou knowest, O God," the speaker asserts, "and so do some others of thine honourable servants know, is but the twilight of that day wherein thou, through him, hast shined upon me before; but the echo of that voice, whereby thou, through him, hast spoke to me before." Here Donne's speaker praises James not as a ruler governing public affairs, but as an agent of God's will in shaping Donne's private life. True, Donne is "careful to point out, constantly, that kings are subject to limitations and restrictions," and need to be wary of rumours and open to the advice of counsellors. ${ }^{28}$ But again, this is difficult to relate to specific issues of controverted policy, whether foreign or domestic. And if this is indeed intended to rebuke James, whom the speaker has just praised - and James's policies certainly had their share of "limitations" - the reference is, if anything, a reflection of Donne's disapproval over James's failure to act aggressively in support of the Palatinate and European protestantism rather than a fear of his falling under the sway of idolatry and papism. 
Finally, we must consider whether such a "political" reading of the Devotions as Cooper's and Marotti's adequately solves the critical problem that they see in the ending of the work. That is, though scholars who have focused on the spiritual nature of the Devotions have insisted on seeing a peaceful reconciliation at the work's conclusion, Cooper instead highlights the overwhelming Angst that overcomes the speaker in the final meditation when he learns that his recovery is temporary and that he will inevitably fall again into sickness. Furthermore, he explains Donne's fear of relapse solely in political terms, however questionable. But although an awareness of the political climate during which Donne wrote the Devotions may add to the poignancy of the work, there is no conclusive evidence that political considerations either informed it or that Donne intended it to have a specific and definable political effect. On the contrary, Donne and his contemporaries spoke of the Devotions only in pietistic, never in political, terms. In a letter to Sir Robert Ker, Donne himself explicitly refers to the Devotions as "the meditations had in my sicknesse ... [that] may minister some holy delight." John Chamberlain writes to Carleton of "Dr. Donnes Devotions in his sicknes newly come abrode, wherein are many curious and daintie conceits, not for common capacities, but surely full of pietie and true feeling." Even in sending a dedication copy to the exiled Queen of Bohemia, at best Donne hopes to comfort her and urge her to bear her crosses and afflictions, as she has done thus far, with patience and faith. The only possible political reference here is to events in the Palatinate. And even in the 1655 Dutch translation of the Devotions, appearing shortly after the first Anglo/Dutch War (1648), the translator Johannes Grindal likewise spoke of nothing but personal piety. In his words "To the Reader," the Devotions "is the right lye to cleanse the eyes of our conscience; the right means to bring us to the right knowledge of our Creator, of our selves." ${ }^{29}$ The deliberate absence of politics in a work published in early 1624, precisely when political worries seem to have dominated the concerns of Donne and his fellow citizens, may rather express Donne's own profound disappointment both at James' failure to support the Palatinate and at Donne's own failure to advance as a consequence of his mission to the Continent. Contrary to what most scholars have assumed, it looks as though Donne's disappointment may have caused him suddenly - and surprisingly - to turn away from politics and towards a pietism that allowed him to escape from just such worldly emptiness, whereas earlier he had embraced such an approach.

Although we may question Cooper's (mis)use of politics founded upon incomplete information as a means of solving critical problems in the Devo- 
tions, we should note that he anticipates the recent flowering of interest in the political/historical contexts of literary and other texts. ${ }^{30}$ The new historicist methodology, however, must not be regarded as the only acceptable - or even the most appropriate - critical perspective in all circumstances or for all problems. In a recent essay re-examining this now popular critical approach, Edward Pechter raises some questions regarding its methodology, and particularly its tendency to "view history and contemporary political life as determined, wholly or in essence, by struggle, contestation, power relations, libido dominandi." One of the main problems with this approach "is the way the new historicists ignore the contrasting rhetorical situations of the texts they discuss. "Morever, such a methodology results in "the new historicists' tendency to deemphasize passages whose affective power seems unusually great," or to read everything in political terms. ${ }^{31}$ Ironically, this latter problem underscores an important shortcoming in endeavoring to read the Devotions in purely political terms. Indeed, these observations find no better manifestation then Cooper's treatment of the Devotions. Although he offers his reading as a way of accounting for the striking fear of relapse with which the work closes, for example, his analysis insists that the political allusions must represent Donne's concern with the power of the kingdom. Consequently, he ignores the poignant outbursts of doubt, hope, piety, and fear that characterize Donne's speaker as he undergoes first the shock of affliction and then the shock of recovery. Moreover, if the new historicism's "persuasive capacity depends first of all on our believing the assumption that the will to power determines human activity and social organization," 32 then Donne's Devotions is, ironically, an expressly anti-new historicist work. Written at a time when Donne seems to have given up any hope of political influence or power, that is, the Devotions might very well reflect his turning away from the world of politics and turning toward a world that transcends everyday weariness. Indeed, perhaps the most affecting moment in the work occurs when the speaker realizes in Devotion XIX that he has not died, and hence cannot escape precisely this world of power, failure, and above all, sinfulness that has caused Donne himself so much recent trauma and pain.

The parallels between the emotional and psychological distress experienced by Donne and his speaker are striking. Contrary to what scholars generally assume, that is, Donne's speaker in the Devotions never prays for physical recovery. Rather, he echoes Donne's own disappointment in the active, earthly, political life as he longs not for physical recovery and further engagement in the world but for the triumphant moment when his soul can join Christ in Heaven. After asserting that "the whole course of life is but an 
active death" (Prayer XVIII, p.96), Donne's speaker concludes the eighteenth devotion with his eyes set firmly on heaven, not on the pains and sufferings of this world. Looking forward to the Last Judgment, when "this soul, now newly departed to thy kingdom, may quickly return to a joyful reunion to that body which it hath left," he is overcome by joy as he contemplates the moment "that time may be swallowed up in eternity, and hope swallowed in possession, and ends swallowed in infiniteness, and all men [that are] ordained to salvation in body and soul be one entire and everlasting sacrifice to thee, where thou mayst receive delight from them, and they glory from thee, for evermore" (Prayer XVIII, pp.96-97). When his hope for union with God is blasted by physical recovery, however, the speaker can only cry out his readiness to "deliver [himself] over to [God] this minute, if this minute [God] wouldst accept [his] dissolution" (Prayer XXIII, p.126). As these final lines from the Devotions demonstrate, this work ends with Donne's speaker shaking in fear and pleading to be preserved through death from relapses of the spirit. Cannot one as readily hear in the moving cries of his speaker echos of Donne's own frustrations and disappointments at failing to move his sovereign to act aggressively and decisively in response to the growing calamities facing Protestantism in Europe? Or, to put it another way, can one not help but notice how strikingly the turning away from this world of sinfulness and fear that Donne's speaker so profoundly expresses in the Devotions parallels Donne's own turning away from the world of politics as a result of the series of disappointments that he had recently suffered?

If in its day, Donne's Devotions seems to have been read for its piety rather than for its political intent, then what is the significance of the curious ending in which fear of relapsing into sin rather than thankfulness to God for physical recovery overcomes the speaker? Although scholarship on the Devotions thus far traditionally has assumed that the work, in keeping with its formal nature as a meditative account of Donne's spiritual self-combat during his near fatal illness, moves from initial anxiety at his fall into sickness towards a final moment of peace brought on by his physical recovery, a careful reading of the final devotions highlights the speaker's tremendous concern with misery and sinfulness. This growing anxiety contrasts sharply with the expressions of unconditional joy in the fourteenth and eighteenth devotions when the speaker lay perilously on the verge of death. This concern also far exceeds the laments on sickness and sin that dominate the early devotions. While it is not possible to do justice to the argument here, in order to read the ending properly, it is important to recognize that the speaker explicitly confesses himself throughout the Devotions as Elect, despite his acute awareness of his 
own sinfulness. ${ }^{33}$ Contrary to Cooper's assertion, however, the fear of relapse in the final two devotions hardly functions as a warning to James of the dangers of Papism. Rather, it highlights the anxiety that overcomes the elect of God who, though he enjoys assurance of salvation, nevertheless knows that as long as he remains on this earth, he will fall again and again into sin, even though to be sure, he can never fall completely away from God. Far from expressing criticism of public policy, whether foreign or domestic, the Devotions is rather an anatomy of Perseverance, an experience appropriate only to the elect who despite their assurance of salvation, can never be free from sinfulness while on earth. It is a dramatization of the emotions which afflict the godly as they attempt to humble themselves before God, repent their sins, and bear their crosses patiently as they await their final moment of peace, a peace that comes with a final escape from - and not an engagement in - the world of politics, diplomacy, and worldly men. ${ }^{34}$

While an accurate political reading - one more scrupulous than we have had thus far - may add to the poignancy and emotional depth of the work, particularly in light of the political failures and disappointments that Donne had suffered just prior to his writing the Devotions, one must remain cautious, for not all texts are equally amenable to this approach. Awareness of the true political and historical situation leading up to the publication of the Devotions reveals that in this work, a Donne psychologically distressed by the failure of his mission with Doncaster to persuade King James to act decisively on behalf of the Palatinate offers a striking and profound turning away from the world of politics as he realizes the suffering that this world inevitably brings and laments his failure to escape from its miseries into the eternal comfort of Heaven. Or to put it another way, a new historicist reading, as we have seen, ironically points up how "anti-historical" a work the Devotions in fact is. In short, it becomes clear why ultimately in the Devotions - and perhaps this is Donne's point - piety and poetry transcend politics.

Oakland University

\section{Notes}

1. All dates are in new style, unless otherwise indicated.

2. See R.L. Abrahamson, "The Vision of Redemption in Donne's Devotions upon Emergent Occasions," Studia Mystica 6.i (1983), 62-69; N.J.C. Andreasen, "Donne's Devotions and the Psychology of Assent," Modern Philology 62 (1965), 207-216; Gerald H. Cox, III, "Donne's Devotions: A Meditative Sequence on Repentance," Harvard Theological Review 66 (1973), 331-351; Jonathan Goldberg, "The Understanding of Sickness. in Donne's Devotions," Renaissance Quarterly 24 (1971), 507-517; Thomas J. Morrissey, 
"The Self and the Meditative Tradition in Donne's Devotions," Notre Dame English Journal 13 (1980), 29-49; Dan Noel Smith, "The Artistry of John Donne's Devotions," University of Dayton Review 10,i (1973), 3-12; and Thomas Van Laan, "John Donne's Devotions and the Jesuit Spiritual Exercises," Studies in Philology 60 (1963), 191-202. Although these essays focus on varying aspects of Donne's Devotions, all assume a movement from sickness and discord to recovery and peace.

3. See Robert M. Cooper, "The Political Implications of Donne's Devotions," in Gary A. Stringer, ed., New Essays on Donne (Salzburg Studies in English Literature) (Salzburg: Institut fur Englische Sprache und Literatur, 1977), 192-210. Cf. Arthur Marotti, John Donne: Coterie Poet (Madison: University of Wisconsin Press, 1986), pp.276, 287. 349. Cooper responds particularly to Andreasen's "Donne's Devotions and the Psychology of Assent."

4. Cooper, pp.192-196.

5. See David Novarr, The Making of Walton's 'Lives' (Ithaca: Cornell University Press, 1958), 29-30 et passim; Judith H. Anderson, Biographical Truth: The Representation of Historical Persons in Tudor-Stuart Writing (New Haven: Yale University Press, 1984), pp. 57-61.

6. Izaak Walton, The Life of Dr. John Donne, in John Donne: Devotions upon Einergent Occasions (Ann Arbor: The University of Michigan Press, 1959), p.xxv; R.C. Bald, John Donne: A Life (Oxford: The Clarendon Press, 1970), p.455.

7. Paul R. Sellin, 'So Doth, So Is Religion': John Donne and Diplomatic Contexts in the Reformed Netherlands, 1619-1620 (Missouri: University of Missouri Press, 1988), pp.166-168.

8. Buckingham and Charles set off on February 18, 1622 old style, which becomes February 28, 1623 when translated into new style. The date for the issuance of the Directions remains August 4, 1622. For accounts of the growing discontent over James' failure to act decisively in support of the Palatinate, please see the Calendar of State Papers, Domestic Series, v. 10 (1619-1623), ed. Mary A. E. Green (London: Longman, 1858); and Valaresso to the Doge, March 1, 1623, in the Calendar of State Papers, Venetian Series, v.17 (1621-1623), ed. Allen B. Hinds (London: 1911). The accounts of the Dutch ambassador in London, Noel de Caron, also underscore this growing discontent on the part of the English citizenry. See, for example, his letters to the States General from December 25, 1621, to March 13, 1623, printed in The British Museum, London, "Engelsche depeches, berustende in het Rijks Archief te s'Gravenhage," Documents on British Dutch Relations. Deposited in the British Museum by order of Viscomte Palmerston, Secretary of State, December 20, 1848, 11 reels. Microfilmed by the Bancroft Library, The University of California, March 4, 1957, \#0157, reel 5.

9. In this sermon, Donne stresses the need for the church to follow the "Orders" or "Priviledges which godly Princes, out of their pietie have afforded" preachers such as himself, particularly those which this "Royall and religious Head of these Churches within his Dominions hath lately had occasion to do" [George R. Potter and Evelyn M. Simpson, The Sermons of John Donne (Berkeley, The University of California Press, 1959), vol. IV, sermon \# 7, pp.198-199]. See also the last half of the sermon, pp.201-209, in which Donne speaks specifically in support of the Directions to Preachers. Although Donne expresses faith in the constancy of James's religion throughout this sermon, there are undertones of dissatisfaction. In his John Donne: A 
Life, R.C. Bald writes that "Donne's defence of the King's directions scarcely touched the real issues" (p.434) and in a letter to Carleton in September, 1622, John Chamberlain writes "on the 15th of this present the Dean of Paules preached at the Crosse to certifie the Kings goode intention in the late orders concerning preachers and preaching, and of his constancie in the true reformed religion ..., but he gave not great satisfaction, or as some say spake as yf himself were not so well satisfied" [The Letters of John Chamberlain, ed. Norman E. McClure (Philadelphia: The American Philosophical Society, 1939), v.II, p.451]. Rather then suggesting that Donne feared James' return to popery, this dissatisfaction may instead reflect his concern over James's failure to act aggressively on behalf of the Palatinate. Indeed, Donne may be referring in this sermon to mounting discontent amongst the citizenry regarding James' failure to act in this regard when, in speaking of God's power, he says:

But I speake of this subject, especially to establish and settle them, that suspect Gods power, or Gods purpose, to succour those, who in forraine parts, grone under heavie pressures in matter of Religion, or to restore those, who in forraine parts, are devested of their lawfull possessions, and inheritance; and because God hath not done these great workes yet, nor yet raised up meanes, in apparance [sic], and in their apprehension, likely to effect it, That therefore God likes not the cause; and therefore they begin to bee shaked in their owne Religion at home, since they thinke that God neglects it abroad.

Potter and Simpson, IV, p. 183.)

10. Donne to Goodere, September 1622, Letters to Severall Persons of Honour by John Donne, ed. Charles E. Merrill, Jr. (New York: 1910), p.200. This letter also demonstrates the careful attention Donne paid to events in Bohemia.

11. Doncaster to Donne, 1622, Edmund Gosse, The Life and Letters of John Donne (London: 1899), v.II, pp.160-61.

12. Donne to Roe, December 1, 1622, Gosse, v.II, pp.1739675.

13. Potter and Simpson, v.IV, p.254.

14. Marotti, p.287.

15. From 1619 on, Chamberlain's letters to Carleton and the Venetian Ambassador's letters to Venice [see C.S.P., Venice, vols. 16 \& 17], reveal England's deep interest in the Palatinate and the fate of the King and Queen of Bohemia. The letters of Caron, the Dutch Ambassador to London during these years, similarly reveals the concern that the English court and people felt for the events occuring in the Palatinate. See, for example, Caron's letters to the States General, recorded in "Engelsche depeches," from December 25, 1621, to October 7, 1623. Cf. Donne to Goodere, September 24, 1622, Letters to Severall Persons of Honour, pp. 182-183. This letter, too, chronicles the events as they unfolded in Bohemia, thereby revealing the deep concern that Donne felt for them.

16. For example, on May 22, 1623, the Venetian Ambassador wrote from London, “A Gentleman has reached here in twelve days from Spain, sent expressly by the Prince of Wales with a letter to his sister, asuring her that he will on no account consent to the marriage before he has obtained the restitution of what belongs to her, and brought her the rest and peace which he desires for her" (C.S.P.Venice, v.18). In detailing the various changes that occured in English policy toward the events in Bohemia, the Dutch Ambassador Caron similarly recounts how the Spanish match became contingent upon 
the restoration of the Palatinate. His letter of July 30, 1622, for example, relates not only that the Infanta has agreed upon the conditions of the marriage, but, more importantly, that the King will support this marriage only if the Palatinate is restored. Indeed, as Caron reports on December 22, 1623 (Charles has returned to England without the Infanta), although Spain refuses to return the Palatinate until after the match, the King insists that this restoration must take place before the wedding.

17. C.S.P.Venice, v.18, June 16, 1623; Chamberlain to Carleton, January 3, 1624, v.II, p.537.

18. For a full analysis of Donne's Catholic background, see Dennis Flynn, "Donne's Catholocism: I" Recusant History 13 (1975-76), 1-17 and "Donne's Catholocism: II" Recusant History 13 (1975-76), 178-195. Cf. R.C. Bald, John Donne: A Life (New York: Oxford University Press, 1970), pp. 39-40, 61-68. Ignatian readings of the Donne's poetry and his Devotions include: Louis L. Martz, The Poetry of Meditation: A Study in English Religious Literature of the Seventeenth Century (New Haven: Yale University Press, 1954); Thomas Van Laan, "John Donne's Devotions and the Jesuit Spiritual Exercises," Studies in Philology 60 (1963), pp. 191-202; Anthony Raspa, "Introduction" to his edition of the Devotions (Montreal: McGillQueen's University Press, 1975), pp. xiii-xl; Sister Elizabeth Savage, ed., John Donne's Devotions Upon Emergent Occasions (Salzburg: Institut fur Englisch Sprach und Literatur, 1975), pp. liii-cii; and R. L. Abrahamson, "The Vision of Redemption in Donne's Devotions Upon Emergent Occasions," Studia Mystica, 6 (1983), pp. 62-69.

19. Anderson, pp. 19, 57, 61, 69. Anderson's study builds upon Stephen Greenblat's important work, Renaissance Self-Fashioning: From More to Shakespeare (Chicago: University of Chicago Press, 1980) and David Novarr's The Making of Walton's Lives. Note, too, that Anderson (pp.58-65) explains how Walton made revisions in his Lives that reflected the changing historical times, and that Walton constantly interpreted and reinterpreted the events in Donne's life.

20. Anderson, p.69.

21. See Paul R. Sellin, John Donne and 'Calvinist' Views of Grace (Amsterdam: 1983), pp.1-50; Mary E. Arshagouni, John Donne's Devotions Upon Emergent Occasions: A Puritan Reading (Dissertation: University of California, Los Angeles, 1988), pp. 341-346.

22. Indeed, the growing tension between what scholars now call the via media "Anglican" church and more radical Puritans within England in early 1640 may very well have been the impetus for Walton's insistence on defining Donne as a true son of the post-Laudian "Anglican" church, though of course he would not use these terms. Donne's own son, John Donne, Jr., may very likely be alluding to this very problem in remarks made on the 1640 printing of his father's Sermons. According to John Donne, Jr.,

... Upon the death of my Father, I was called awaie, beeinge commaunded by the Kinge, and encouradged by most of the cheefe men in the Kingdome, to recollect and printe my Fathers Sermons. ... I had in my proceedings with the Bysshop of Canterburies Chaplaines, (who were to licence them), manie disputes, thay offeringe to expunge manie things, which hee openly preached, and, in the Bysshops hearinge, withoute anie dispute, all his lyfetime: by which 
meanes, I soe farr incurred the Bysshops displeasure, that hee thrice put me by the Cannonry.

See Bald, pp.575-576. One cannot help but wonder just what were those "manie things, which [Donne] openly preached" that the Bishops in 1640 found so objectionable.

23. Selliı, 'So Doth, So ls Religion', p.vii.

24. According to Professor Sellin, moreover, "there is little doubt," that Donne's thoughts were consumed with the problems facing protestantism in Europe and "that about this time [1621-22] Donne did in fact air his opinions publicly about Bohemia, the papacy, and the consequences of neutrality for the Reformed religion." Ibid, p.169.

25. ???

26. Cooper, pp.192, 203-04.

27. John Donne, Devotions upon Emergent Occasions, edited by Anthony Raspa (Montreal: McGill-Queen's University Press, 1975). All subsequent references will be from this edition.

28. Cooper, pp.198-201.

29. Donne to Ker, February 1624, Letters, pp.2 14-15; Chamberlain to Carleton, February 21, 1624, p.545; Donne to the Queen of Bohemia, 1624, Gosse II, p.205; Grindal, "To the Reader," reprinted in Paul R. Sellin, John Donne and 'Calvinist' Views of Grace, pp.59-61.

30. See, for example, Louis Montrose, "Renaissance Literary Studies and the Subject of History," English Literary Renaissance 16:i (Winter 1986), pp.5-12; and Jean Howard, "The New Historicism in Renaissance Studies," English Literary Renaissance 16:i (Winter 1986), pp.13-43.

31. Edward Pechter, "The New Historicism and Its Discontents: Politicizing Renaissance Drama," Publications of the Modern Language Association 102:iii (May 1987), pp.292-299.

32. Ibid, p.301.

33. Mary Arshagouni, "Election in John Donne's Devotions Upon Emergent Occasions" (unpublished essay).

34. Please see my study, John Donne's Devotions Upon Emergent Occasions: A Puritan Reading, for a full account of this reading of the Devotions. 